\title{
Effect of continuous infusion of gonadotrophin-releasing hormone in ewes at different times of the year
}

\author{
A. M. Shareha,* W. R. Ward and Kathleen Birchall† \\ Department of Veterinary Clinical Studies, University of Liverpool, \\ Leahurst, Neston, Wirral L64 7TE, U.K.
}

\begin{abstract}
Summary. Gn-RH ( $3 \mu \mathrm{g} / \mathrm{hr}$ for $8 \mathrm{hr}$ ) evoked a surge of LH in ewes during the anoestrous season which was of similar peak height to that found at oestrus but of shorter duration. When Gn-RH was given on 3 consecutive days, the response was considerably reduced on the 2 nd and 3 rd day. Follicles grew as a result of Gn-RH infusion but peripheral plasma oestrogen concentration did not increase. During the anoestrous season $9 / 18$ ewes ovulated but only $1 / 6$ did so at mid-anoestrus. Mature follicles or a $\mathrm{CL}$ were found in $15 / 18$ ewes that had increased peripheral plasma progesterone concentrations for 1-5 days (11 ewes) or 9-14 days (4 ewes). The concentrations of progesterone found were always lower than those observed during the normal cycle. In the breeding season 10/11 ewes ovulated but there was no evidence that the induced $\mathrm{CL}$ were maintained.
\end{abstract}

\section{Introduction}

Since Gn-RH was synthesized by Matsuo, Arimura, Nair \& Schally (1971), and shown to have the same biological activity as natural Gn-RH (Schally, Redding, Matsuo \& Arimura, 1972), it has been used to bring about ovulation in many species, including sheep (Reeves et al., 1972). A single injection of Gn-RH releases both LH and FSH (Reeves et al., 1972; Nillius \& Wide, 1972; Kaltenbach et al., 1974). There are, however, considerable increases in the release of both hormones when a prolonged intravenous infusion is carried out (Arimura, Debeljuk \& Schally, 1972; Debeljuk, Arimura \& Schally, 1973). During the oestrous cycle of the ewe there are phases of follicular growth from Days 6 to 9 and 13 to 15 (Smeaton \& Robertson, 1971), but the follicles regress before maturing. In the anoestrous ewe, Cole \& Miller (1935) deduced from changes in the vaginal smear that early and late in the anoestrous season ewes exhibited a semi-cyclic pattern in ovarian activity. Furthermore, Hammond (1944) and Robinson (1950) have shown that there are phases of continual growth and regression of follicles during anoestrus.

In the present investigation, attempts were made to stimulate the growth of follicles during the anoestrous season by administering Gn-RH on 2 consecutive days and then to bring about ovulation of the matured follicles on the 3rd day of treatment. In the cyclic ewe, attempts were made with Gn-RH to induce multiple ovulation of those follicles which are present from Days 6 to 9 and 11 to 13 but which normally regress.

\section{Materials and Methods}

\section{Animals}

Scottish Blackface ewes were used during the early (1 April-15 May), mid- (16 May-30 June) and late (1 July-1 September) anoestrous season 1973 and during the following breeding season (October 1973-February 1974). During this period the ewes were housed indoors and run with a vasectomized ram, except during the infusion periods. Before allocation to experimental groups,

* Present address: Faculty of Agriculture, University of Tripoli, Tripoli, Libya.

$\dagger$ Present address and address for reprint requests: Department of Biological Sciences, Napier College, Edinburgh, U.K. 
one carotid artery was raised to a subcutaneous position to permit intracarotid infusion in the conscious animal, and oestrous behaviour was observed to determine the length of the oestrous cycle for at least two cycles. Hormone concentrations were determined throughout one complete oestrous cycle.

Indwelling polyethylene catheters were placed in one jugular vein for collection of blood samples and in one carotid artery. The synthetic decapeptide Gn-RH (I.C.I. 82,286: I.C.I., Alderley Park, Macclesfield, Cheshire), was stored as an aqueous solution $(10 \mathrm{mg} / \mathrm{ml})$ at $-15^{\circ} \mathrm{C}$. It was diluted to $24 \mu \mathrm{g}$ in $35 \mathrm{ml} 0.9 \% \mathrm{NaCl}$ immediately before infusion.

After a pilot experiment to compare the effect of continuous infusion of $\mathrm{Gn}-\mathrm{RH}$ with single or repeated injections of the drug (see 'Results'), continuous infusion was used in all further investigations. Animals were infused for 1, 2 or 3 days with either $3 \mu \mathrm{g} \mathrm{Gn}-\mathrm{RH} / \mathrm{hr}$ for one 8 -hr period during each $24 \mathrm{hr}$ (treatment groups) or with an equal volume of saline (control groups) using two-channel peristaltic pumps (Watson-Marlow Ltd, Falmouth, U.K.). Blood samples $(5,10$ or $20 \mathrm{ml}$ ) were collected into heparinized syringes (100 units/ml whole blood) at $15 \mathrm{~min}$ before infusion and at $5,10,20,30,45,60,90$ and 120 min during infusion. Thereafter, samples were taken at 2 -hr intervals up to 14 or $36 \mathrm{hr}$ and then daily over the next 14-16 days. All samples were centrifuged without delay and the plasma stored at $-15^{\circ} \mathrm{C}$ until assayed for progesterone, total oestrogens and $\mathrm{LH}$.

\section{Experimental design}

In the breeding season, infusions were carried out during Days 6, 7 and 8 or Days 11,12 and 13 of the oestrous cycle (Day $1=$ oestrus). In the anoestrous season, infusion was carried out during the early, mid- and late season (see Table 3 for numbers of ewes). (In the initial experiments hormone concentrations in ewes infused with saline were the same as those in untreated ewes sampled during the same period and control ewes were, therefore, not infused in later experiments. Only in the early anoestrous season were all control ewes infused with saline.)

With the exception of $7 / 16$ control ewes, the ovaries of all animals were examined by endoscopy 40-45 hr after the end of the last infusion, using a fibre-optic system (R. Wolf, $7134 \mathrm{Knittlingen,}$ West Germany). The sizes of the follicles were estimated with reference to the size of forceps used to hold the ovaries. Follicles with an estimated diameter of more than $7 \mathrm{~mm}$ were classified as large.

\section{Radioimmunoassay of hormones}

Oestrogens. Total oestrogens were measured by a radioimmunoassay procedure similar to that of Hotchkiss, Atkinson \& Knobil (1971). Diethyl ether $(4.0 \mathrm{ml})$ was used to extract total oestrogens from plasma samples $(2 \cdot 0-4 \cdot 0 \mathrm{ml})$, and the radioimmunoassay set up in a total volume of $0.2 \mathrm{ml}$. This consisted of $0 \cdot 1 \mathrm{ml}\left[2,4,6,7-{ }^{3} \mathrm{H}\right]$ oestradiol-17ß (sp. act. $85-105 \mathrm{Ci} / \mathrm{mmol}$ ) containing 28,000 $\mathrm{d} / \mathrm{min}$ and $0 \cdot 1 \mathrm{ml}$ total oestrogen antiserum (batch SLC $10-\mathrm{C}$ ) at $1: 4000$ dilution with $0 \cdot 1 \mathrm{M}$ phosphatebuffered saline, $\mathrm{pH} 7 \cdot 0$, containing $0.1 \%$ gelatine (PBSG). The system was incubated overnight at $4^{\circ} \mathrm{C}$, after which $1.0 \mathrm{ml}$ of a suspension containing $0.0025 \%$ dextran T.40 with $0.25 \%$ Norit A charcoal in PBSG was added to separate free from bound fractions. The dextran-coated charcoal was allowed to react in the assay for $\mathbf{1 0} \mathrm{min}$ before centrifugation and scintillation counting of the bound fraction.

The cross-reactivity of the total oestrogen antiserum was $80 \%$ for oestrone and $10 \%$ for oestriol when oestradiol $-17 \beta$ was $100 \%$.

The efficiency of the extraction procedure was measured by the recovery of labelled oestradiol-17 $\beta$ from different volumes of plasma from a castrated ram. The mean $( \pm$ S.D. $) \%$ recoveries were $84 \cdot 7 \pm 10 \cdot 7$ (no. of observations, $n=52$ ) from $2 \cdot 0 \mathrm{ml} ; 84 \cdot 2 \pm 9 \cdot 2(n=54)$ from $3 \cdot 0 \mathrm{ml}$ and $84 \cdot 5 \pm 9 \cdot 7(n=66)$ from $4.0 \mathrm{ml}$. When $20-100 \mathrm{pg}$ oestradiol-17 $\beta$ were added to plasma, the measured amounts were closely related to those added giving a correlation coefficient of +0.998 . From the standard curve for oestradiol-17 $\beta(5-150 \mathrm{pg})$ the limit of sensitivity of the assay was found to be less than $20 \mathrm{pg} / \mathrm{assay}$ tube. However, based on the value for the water blank \pm 2 S.D. $(5 \cdot 78 \pm 9 \cdot 02 ; n=18)$ the limit of sensitivity was considered to be $14.80 \mathrm{pg} /$ assay tube, i.e. $3.7 \mathrm{pg} / \mathrm{ml}$ plasma. When total oestrogens 
were assayed using $2 \cdot 0,3.0$ or $4.0 \mathrm{ml}$ of the same plasma there was no significant difference in the measured concentration of oestrogen.

The intra- and inter-assay variation was determined by the method of Rodbard (1971). The inter-assay variation for the same duplicate plasma samples in $\mathbf{1 0}$ consecutive assays gave $F$ ratios which, with the exception of one assay, were not significant. The intra-assay variation was expressed as the coefficient of variance measured for duplicate samples having concentrations within 5 ranges between 5 and $150 \mathrm{pg}$, and was $5 \cdot 8-9 \cdot 9 \%$.

Progesterone. A double-antibody technique was used to separate free from bound moieties. Plasma samples $(0.05-0.5 \mathrm{ml})$ were extracted once with $2.0 \mathrm{ml}$ hexane (b.p. $\left.67-70^{\circ} \mathrm{C}\right)$. The standard curve was set up with each tube containing the dried residues of $2 \mathrm{ml}$ hexane and $0 \cdot 1 \mathrm{ml}$ standard solutions containing $0,20,50,100,200,300,400$ or $500 \mathrm{pg}$ progesterone. Progesterone antiserum diluted to $1: 5000$ in $0.1 \mathrm{ml} 0.1 \mathrm{M}$ phosphate-buffered saline at $\mathrm{pH} 7.0$ (PBS), containing 0.03 Methylenediamine tetra-acetic acid and $0.1 \%$ normal rabbit serum, was added to all standard curve and sample tubes, except non-specific binding tubes which received $0.1 \mathrm{ml}$ vehicle alone, and the tubes were incubated for $30 \mathrm{~min}$ at room temperature. Radioactive progesterone $\left(\left[2,4,6,7-{ }^{3} \mathrm{H}\right]-\right.$ progesterone, sp. act. $100 \mathrm{Ci} / \mathrm{mmol}$ ), $12,000 \mathrm{~d} / \mathrm{min}$ in $0.1 \mathrm{ml} \mathrm{PBS}$, was added to all tubes and to 'total radioactivity' scintillation vials and the tubes were incubated for a further $2 \mathrm{hr}$ at room temperature.

Anti-rabbit gamma globulin $(0.1 \mathrm{ml})$ raised in goats and used at a dilution of $1: 45$ in PBS was added and the incubation continued for $24 \mathrm{hr}$ at $4^{\circ} \mathrm{C}$. The supernatant, obtained after centrifugation of the tubes at $1500 \mathrm{~g}$ for $10 \mathrm{~min}$, was discarded and the precipitate was dissolved in $0.2 \mathrm{ml} 0.1 \mathrm{~N}-\mathrm{NaOH}$ and transferred to vials for counting using a toluene-based scintillation mixture.

In each assay, plasma samples containing radioactive progesterone were included to assess the efficiency of the extraction procedure and the corrections for losses were then applied to other samples in the assay.

Quality control samples of plasma having a low progesterone concentration, and plasma with added progesterone, were also included in the assays. The progesterone concentration in samples was calculated from readings taken from the standard curve plots of $\mathrm{ct} / \mathrm{min}$ bound versus $\log$ dose.

The cross-reactivity of the progesterone antiserum, which was raised in rabbit against a conjugate of $11 \beta$-hydroxyprogesterone with bovine serum albumin, was from 1 to $1.3 \%$ with 21 -hydroxyprogesterone, $17 \alpha$-hydroxyprogesterone and 11 -deoxycorticosterone, and less than $1 \%$ with $20 \alpha$ and 20ß-dihydroprogesterone.

The mean ( \pm S.D.) \% recoveries of radioactive progesterone added to different volumes of plasma from a castrated ram were $81 \cdot 3 \pm 8.8(n=46)$ from $0.05 \mathrm{ml} ; 79.6 \pm 8.5(n=67)$ from $0.1 \mathrm{ml} ; 67 \cdot 3 \pm 12 \cdot 1$ $(n=14)$ from $0.2 \mathrm{ml}$; and $71 \cdot 1 \pm 10.8(n=105)$ from $0.5 \mathrm{ml}$ and were not significantly different from each other.

When various amounts of progesterone $(20-300 \mathrm{pg})$ were added to plasma the correlation coefficient between progesterone added and that measured was +0.998 . From the standard curve for progesterone (for 20-500 pg) the limit of sensitivity of the assay was found to be less than $20 \mathrm{pg} /$ assay tube, but the water blank \pm 2 S.D. was $7 \cdot 54 \pm 13 \cdot 74(n=15)$ and the sensitivity was considered to be $21.28 \mathrm{pg} /$ assay tube, equivalent to $42.56 \mathrm{pg} / \mathrm{ml}$ plasma. When $0.1-0.5 \mathrm{ml}$ plasma was used in the assay, values for progesterone concentration were not significantly different from each other.

A measure of the reproducibility and precision of the assay was obtained from the variance between and within assays. The inter-assay variance calculated from the standard curve indicated the need to reject $2 / 8$ assays. The intra-assay coefficient of variance was between 2.8 and $5.0 \%$ (mean $4.1 \%$ ) in 10 consecutive assays. The inter-assay variance for duplicate samples measured in 9 assays showed the need to reject one assay. The intra-assay coefficient of variance for duplicate samples within different ranges of progesterone concentration was between 6.5 and $16.5 \%$ (mean $7 \cdot 75 \%$ ).

The LH assay was carried out as described by Scaramuzzi, Caldwell \& Moor (1970), with ovine LH (LER-1056-C2) being used for iodination and ovine LH (NIH-LH-S18) as the standard. Thus ovine plasma LH concentrations from this study are expressed in terms of NIH-LH-S18. The anti- 
serum to ovine LH was raised in rabbits in this laboratory and used at a dilution of $1: 50,000$ which bound $48 \%$ of the iodinated hormone. The \% binding with $0.5 \mathrm{ng} /$ assay tube was significantly different from that with $0.7 \mathrm{ng} /$ assay tube. The limit of sensitivity of the assay was therefore taken as $0.7 \mathrm{ng} /$ assay tube (i.e. $1.75 \mathrm{ng} / \mathrm{ml}$ ). When $5-100 \mathrm{ng} \mathbf{L H}$ were added to plasma the correlation coefficient between LH added and that measured was +0.999. The inter-assay coefficient of variance calculated from the standard curve in 10 assays indicated the need to reject two. The intra-assay coefficient of variance for the standard curve was between 2.7 and $6.0 \%$ (mean $4.1 \%$ ) in 10 consecutive assays. The intra-assay variance from duplicate samples measured in six assays was between 10.8 and $17.1 \%$ (mean $13.7 \%$ ).

\section{Results}

In the pilot experiment (Table 1), either a single injection of Gn-RH or two injections, $4 \mathrm{hr}$ apart, on Day 13 of the oestrous cycle resulted in plasma concentrations of LH which were well below those observed in the normal cycle of these ewes, and less than that obtained as a result of a prolonged infusion of Gn-RH during the breeding season (see Text-fig. 1). Endoscopy at 40-46 hr after the first injection revealed only old CL. A large follicle was seen in the ewe which received two injections. These results contrast sharply with those obtained with continuous infusion as described below.

Table 1. Plasma concentrations of $\mathrm{LH}$ after $\mathrm{Gn}-\mathrm{RH}$ given either as one intracarotid injection of $24 \mu \mathrm{g}$ (Ewe 92) or 2 injections each of $24 \mu \mathrm{g}$ (Ewe 94) on Day 13 of the oestrous cycle

\begin{tabular}{|c|c|c|c|c|}
\hline \multirow{2}{*}{\multicolumn{2}{|c|}{ Time from 1st injection (min) }} & \multicolumn{3}{|c|}{ LH (ng/ml) } \\
\hline & & \multirow[b]{2}{*}{ Ewe 92} & \multicolumn{2}{|c|}{ Ewe 94} \\
\hline Ewes 92 and 94 & Ewe 94 & & 1st injection & 2nd injection \\
\hline-15 & 245 & $1 \cdot 6$ & 2 & 26 \\
\hline 10 & 250 & 10 & 19 & 34 \\
\hline 20 & 260 & 20 & 46 & 21 \\
\hline 30 & 270 & 12 & 32 & 18 \\
\hline 40 & 280 & 12 & 23 & 20 \\
\hline 50 & 290 & 24 & 25 & 16 \\
\hline 60 & 300 & 16 & 33 & 15 \\
\hline 70 & 310 & 20 & 24 & 13 \\
\hline 80 & 330 & 21 & 32 & 10 \\
\hline 90 & 360 & 28 & 25 & 12 \\
\hline 120 & 420 & 13 & 18 & 3 \\
\hline 180 & & 4 & 15 & \\
\hline 225 & & $\ldots$ & 3 & \\
\hline $240^{*}$ & & $1 \cdot 5$ & & \\
\hline
\end{tabular}

* Time of 2nd injection for Ewe 94.

The mean plasma $\mathrm{LH}$ concentration in ewes infused for 1-3 days is given in Table 2. Regardless of season, the LH response was significantly smaller $(P<0 \cdot 01)$ during infusion on the 2 nd and 3rd days. The concentrations of LH found in the normal oestrous cycle are compared with those during the first day of infusion of Gn-RH in the breeding season and at different stages of the anoestrous season (Text-fig. 1). In all ewes infused with $\mathrm{Gn}-\mathrm{RH}$ there was a significant increase in plasma $\mathrm{LH}$ concentration which reached a maximum 2-4 hr after the start of infusion and then declined gradually to pretreatment concentrations 10-12 hr later. The period of LH release as a result of infusion $(11.5 \pm 3.2$ (S.D.) hr, 29 ewes) was significantly shorter $(P<0.001)$ than that found in the normal oestrous cycle (18.4 $\pm 3 \cdot 8 \mathrm{hr}, 8$ ewes). The mean value for the Gn-RH-induced peak in plasma concentration of LH observed in the breeding season $(98 \cdot 1 \pm 37 \cdot 1 \mathrm{ng} / \mathrm{ml}, 11$ ewes) was the same, regardless of whether Gn-RH is given during the mid- or late period of the cycle, and was significantly 

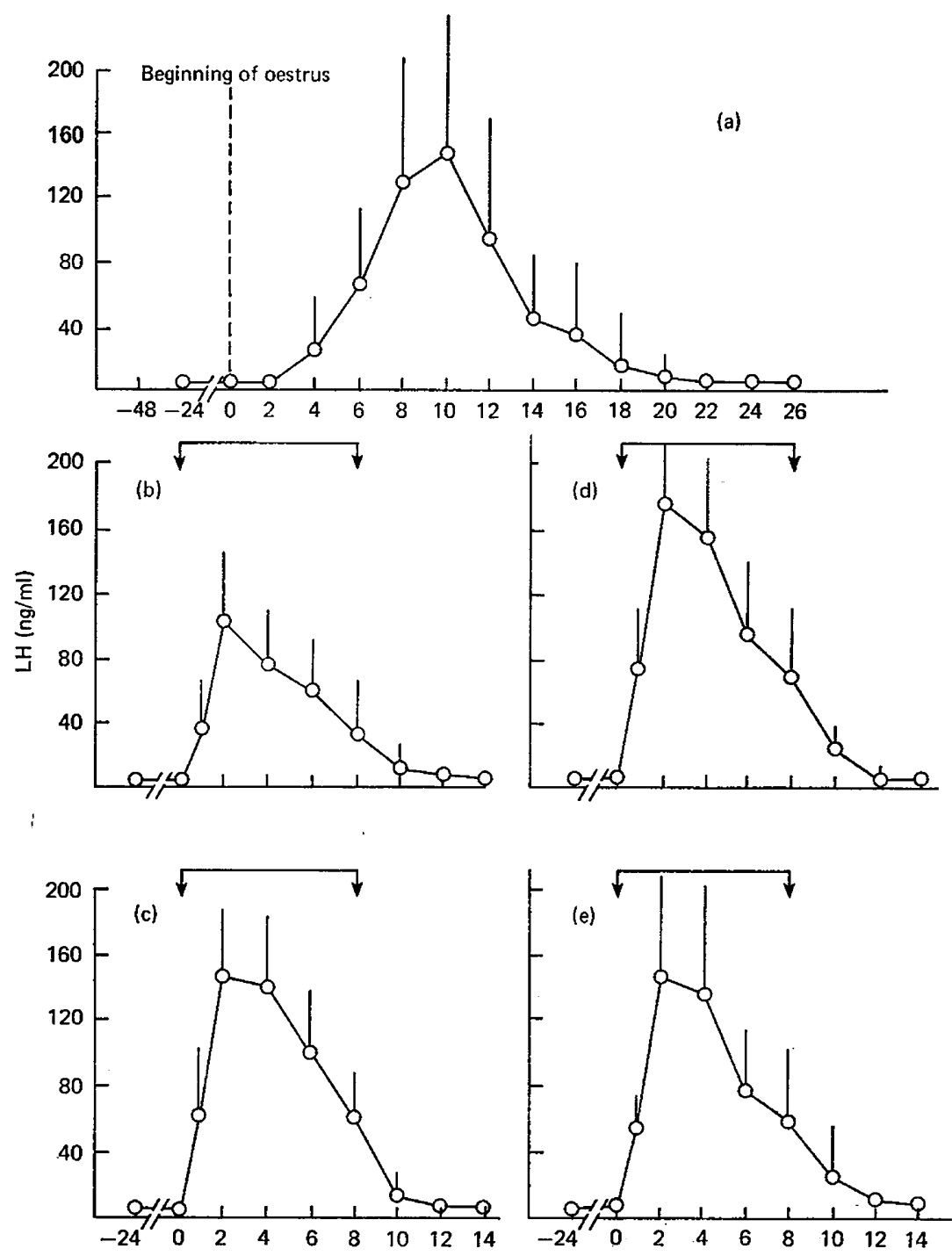

Time $\{\mathrm{hr}$ \}

Text-fig. 1. Comparison of plasma LH concentrations in ewes infused with Gn-RH (horizontal bar) at different times of the year (b, breeding season, September-February, $\mathrm{N}=11$; c, early anoestrus, April, $\mathrm{N}=6$; d, mid-anoestrus, June, $\mathrm{N}=6$; e late anoestrus, August, $\mathrm{N}=6$ ) with that found during spontaneous oestrus (a, $N=8$ ). Points represent means; vertical bars denote S.D.

lower $(P<0.005)$ than that observed in the normal cycle $(138.8 \pm 83.4 \mathrm{ng} / \mathrm{ml}, 8$ ewes $)$. The peak LH concentrations as a result of Gn-RH infusion in the anoestrous ewes were similar in magnitude to the release during the normal oestrous cycle. At all times when infusions were carried out, controls infused with saline had a very low concentration of $\mathrm{LH}(<1.8 \mathrm{ng} / \mathrm{ml})$ which was similar to the values for ewes that were not infused.

The changes in LH concentration in ewes infused with Gn-RH on Days 6, 7 and 8 or Days 11, 12 and 13 of the cycle were similar to those shown in Table 2. Small transient increases above the normal progesterone concentration were seen on each day of infusion and at the end of the last infusion period the progesterone concentration reverted to that of the normal cycle. Of 11 ewes infused with Gn-RH, endoscopy showed that 10 had ovulated. Regardless of the time of the cycle 
Table 2. Plasma concentration of LH (mean \pm S.D., $\mathrm{ng} / \mathrm{ml}$ ) after $\mathrm{Gn}-\mathrm{RH}$ infusion $(3 \mu \mathrm{g} / \mathrm{hr}$ for $8 \mathrm{hr}$ ) to anoestrous and cyclic ewes on each of 2 or 3 consecutive days

\begin{tabular}{|c|c|c|c|c|c|c|c|c|c|c|c|}
\hline \multirow[b]{2}{*}{ Day } & \multicolumn{10}{|c|}{ Time from start of infusion (hr) } & \multirow{2}{*}{$\begin{array}{l}\text { No. of } \\
\text { ewes* }\end{array}$} \\
\hline & -0.25 & 1 & $1 \cdot 5$ & 2 & 4 & 6 & 8 & 10 & 12 & 14 & \\
\hline \multirow[t]{2}{*}{ 1st } & $1 \cdot 4 * *$ & $58 \cdot 1$ & $93 \cdot 4$ & $139 \cdot 6$ & $124 \cdot 7$ & $79 \cdot 8$ & $55 \cdot 5$ & $19 \cdot 3$ & $3 \cdot 8$ & $1 \cdot 3 * *$ & 14 \\
\hline & \pm 0.3 & $\pm 34 \cdot 7$ & $\pm 50 \cdot 2$ & $\pm 62 \cdot 0$ & $\pm 58 \cdot 1$ & $\pm 40 \cdot 8$ & $\pm 35 \cdot 2$ & $\pm 17 \cdot 2$ & $\pm 3 \cdot 2$ & \pm 0.4 & \\
\hline \multirow[t]{2}{*}{ 2nd } & $1 \cdot 4$ & 6.7 & $7 \cdot 7$ & $7 \cdot 5$ & 9.5 & $9 \cdot 4$ & $8 \cdot 3$ & $2 \cdot 2$ & $1 \cdot 5$ & $1 \cdot 2$ & 14 \\
\hline & $\pm 0 \cdot 2$ & $\pm 5 \cdot 5$ & $\pm 5 \cdot 6$ & $\pm 5 \cdot 8$ & $\pm 9 \cdot 1$ & $\pm 11 \cdot 1$ & $\pm 9 \cdot 4$ & $\pm 1 \cdot 3$ & \pm 0.5 & \pm 0.1 & \\
\hline \multirow[t]{2}{*}{3 rd } & $1 \cdot 3$ & 9.9 & 9.0 & $10 \cdot 0$ & $4 \cdot 6$ & 3.5 & 4.8 & 2.6 & 1.3 & $1 \cdot 2$ & 9 \\
\hline & \pm 0.2 & $\pm 7 \cdot 5$ & \pm 8.8 & $\pm 12 \cdot 1$ & $\pm 2 \cdot 9$ & $\pm 2 \cdot 3$ & \pm 5.6 & \pm 2.9 & $\pm 0 \cdot 1$ & \pm 0.0 & \\
\hline
\end{tabular}

* Groups of ewes for 1 st and 2 nd day infusions consisted of 6 in the breeding season and 8 in anoestrus; for the 3rd day infusion there were 3 in the breeding season and 6 in anoestrus.

** Values not significantly different from values in same column; other values for 1st day of infusion were different from those on the 2 nd and 3 rd days, $P<0 \cdot 01$.

when the ewes were infused all came into oestrus at the expected time after the previous oestrus. There were no significant changes in oestrogen concentration as a result of $\mathrm{Gn}-\mathrm{RH}$ or saline infusion. This lack of response was evident throughout the breeding season and anoestrus.

During the infusion of Gn-RH to ewes at different stages of the anoestrous season there was no change in progesterone concentrations, which ranged from 0.04 to $0.12 \mathrm{ng} / \mathrm{ml}$, but after the infusion $15 / 18$ ewes showed increases in progesterone concentrations and in all of these an induced CL or a mature follicle had been observed at endoscopy. Eleven ewes had slight but significant $(P<0 \cdot 001)$ increases in progesterone $(0 \cdot 1-0.8 \mathrm{ng} / \mathrm{ml})$ for $1-5$ days after the end of infusion, and 5 of the 11 had a new CL. High concentrations of progesterone were evident in 4 of the 15 ewes for an extended period of time. During early anoestrus the induced $\mathrm{CL}$ which were present in 2 ewes, were maintained for 9-10 days (2-3 days less than in the normal cycle); however, the peak progesterone concentrations $(2.3$ and $4.3 \mathrm{ng} / \mathrm{ml})$ were considerably less than those observed in the normal cycle $(5 \cdot 2$ and $7.0 \mathrm{ng} / \mathrm{ml})$. Plasma samples taken at least $16 \mathrm{hr}$ before infusion contained high concentrations of oestrogen $(18$ and $28 \mathrm{pg} / \mathrm{ml})$. In 2 ewes infused during late anoestrus, progesterone concentrations were elevated for the normal length of time, reaching peaks of 4.0 and $5.5 \mathrm{ng} / \mathrm{ml}$. In one of the ewes infused during late anoestrus, the LH peak was considerably less than that found in the same animal at oestrus and when it was infused at other times during anoestrus. In one of the control ewes in late anoestrus, spontaneous ovulation had taken place and two $\mathrm{Cl}$ were seen at endoscopy. Although the progesterone concentration was elevated, it was lower than in a normal cycle. Before saline infusion, LH concentrations were higher than baseline but decreasing, as at the end of an LH surge. Three other control ewes had low concentrations of progesterone and $\mathrm{LH}$ at this time.

Table 3. Ovarian changes in ewes infused with $\mathrm{Gn}-\mathrm{RH}$ at different seasons

\begin{tabular}{|c|c|c|c|c|c|c|}
\hline \multirow{2}{*}{$\frac{\text { Group }}{\text { Control }}$} & Season & No. of ewes & $\begin{array}{l}\text { No. of ewes } \\
\text { examined by } \\
\text { endoscopy }\end{array}$ & \multicolumn{2}{|c|}{$\begin{array}{l}\text { Mean no. of } \\
\text { follicles }\end{array}$} & $\begin{array}{c}\text { No. of ewes } \\
\text { ovulating }\end{array}$ \\
\hline & Breeding-Days $6,7,8$ & 3 & 2 & & & $\mathbf{0}$ \\
\hline & Breeding-Days 11, 12, 13 & 3 & 1 & 0.3 & 0.3 & 0 \\
\hline & Early anoestrus & 3 & 2 & 0 & $1 \cdot 2$ & 0 \\
\hline & Mid-anoestrus & 3 & 3 & 1.0 & $3 \cdot 3$ & 0 \\
\hline & Late anoestrus & 4 & 1 & 0 & 0 & $1^{*}$ \\
\hline \multirow[t]{5}{*}{ Treated } & Breeding-Days 6, 7,8 & 6 & 6 & $1 \cdot 0$ & 0.5 & 6 \\
\hline & Breeding-Days 11, 12, 13 & 5 & 5 & 0.6 & $2 \cdot 8$ & 4 \\
\hline & Early anoestrus & 6 & 6 & 0.5 & $6 \cdot 0$ & 3 \\
\hline & Mid-anoestrus & 6 & 6 & $1 \cdot 2$ & 1.9 & 1 \\
\hline & Late anoestrus & 6 & 6 & $0 \cdot 3$ & $2 \cdot 7$ & $5^{*}$ \\
\hline
\end{tabular}

* Spontaneous ovulation in 1 ewe. 
The findings of the endoscopic examinations are shown in Table 3. Treatment with Gn-RH resulted in the appearance of more large follicles and ovulation.

\section{Discussion}

Reeves, Arimura \& Schally (1970) obtained maximum LH concentrations in cyclic ewes following a single injection of $3 \mu \mathrm{g} \mathrm{Gn}-\mathrm{RH}$, but these increases were far below preovulatory $\mathrm{LH}$ levels previously reported (Goding et al., 1969; Niswender, Reichert, Midgley \& Nalbandov, 1969). Although, in the present study, a single injection of Gn-RH released only small amounts of LH and failed to induce ovulation, infusion of the same dose of Gn-RH resulted in a surge of $\mathrm{LH}$ similar to that found in the normal cycle, caused ovulation and was used therefore in all subsequent experiments. Continuous infusion with lower doses (Cumming et al., 1972) might have achieved similar results but there is evidence of poor responses to low doses of Gn-RH (Chakraborty \& Reeves, 1973; Symons, Cunningham \& Saba, 1974). These conflicting results may be due to differences in potency of the Gn-RH preparations, differences in the period of anoestrus in which the ewes were treated, or both.

Although more large follicles developed after infusion on 3 days than on either 1 or 2 days, none of the infusions resulted in multiple ovulations. It appears therefore that in the breeding and anoestrous seasons only one follicle is naturally primed at the time of infusion and able to respond to gonadotrophins by ovulating. The reduced pituitary response to $\mathrm{Gn}-\mathrm{RH}$ on the 2 nd and 3rd day of infusion is in agreement with the findings of Symons et al. (1974) and may be explained by desensitization of the pituitary to the hormone. A limited investigation in this laboratory has shown that the pituitary content of $\mathrm{LH}$ after an $8 \mathrm{hr}$ infusion of $\mathrm{Gn}-\mathrm{RH}$ was $333 \mu \mathrm{g}$ (unpublished data), presumably a 'non-releasable' store under these conditions.

The quantitative and qualitative similarity in $\mathrm{LH}$ response to Gn-RH administered at different times during the cycle has also been reported by Rippel, Moyer, Johnson \& Mauer (1974). The lower concentration of $\mathrm{LH}$ observed following infusion with Gn-RH during the cycle when compared with the LH surge at oestrus may be due to the presence of high concentrations of endogenous progesterone. Evidence in support of this is provided by Pant \& Ward (1973), who reported suppression of pituitary responsiveness to single injections of a small dose of $\mathrm{Gn}-\mathrm{RH}$ by administration of progesterone in physiological amounts to anoestrous ewes for 14 days. On the other hand, neither Chakraborty \& Reeves (1973) nor Cumming et al. (1972) were able to reduce the LH response to similar low doses of Gn-RH. In both these experiments, however, Gn-RH was given by continuous infusion which would provide continuous stimulation of the pituitary and thus might be capable of overcoming any suppressive effect of progesterone.

The lack of a direct relationship of Gn-RH release with $\mathrm{LH}$ release (Nett, Akbar \& Niswender, 1974; Foster, Holland, Jeffcoate \& Crighton, 1974) and the stimulation by oestrogens of LH release (Radford, Wheatley \& Wallace, 1969; Jonas et al., 1973) would indicate a role for steroid hormones acting in concert with Gn-RH to modulate gonadotrophin release. Thus a more likely explanation for the reduced response to Gn-RH during the luteal phase is the absence of the oestrogen surge since it has been shown also that oestrogen enhances the response to Gn-RH (Reeves, Arimua \& Schally, 1971). The absence of oestrogen would also account for the lack of oestrous behaviour in all the ewes in the treatment groups.

Since all ewes infused with Gn-RH had LH peaks of shorter duration than those associated with a spontaneous oestrus, this may be one factor contributing to the low rate of ovulation in anoestrus, but the high ovulation rate in the breeding season, despite the shorter LH peak, indicates the probable role of the hormonal background in ovulation. The lack of a suitable balance of steroids in the ewe in anoestrus may therefore be a second, and major, factor leading to the low ovulation rate.

The similarity in the magnitude of $\mathrm{LH}$ response to $\mathrm{Gn}-\mathrm{RH}$ at different times of the anoestrous season is in agreement with work of Reeves, Tarnavsky \& Chakraborty (1974). Since the amount of LH in the pituitary is similar in anoestrus to that just before oestrus (Roche, Foster, Karsch, Cook \& Dziuk, 1970), and the LH release at oestrus is similar to that released in anoestrus by Gn-RH, 
the relatively low level of $\mathrm{LH}$ released in the normal anoestrous ewe cannot be attributed to either a pituitary deficiency of LH or an inability to release the hormone.

The ovulation response during anoestrus was similar to that found by Domanski \& Kochman (1968), although Reeves et al. (1974) and Rippel et al. (1974) reported low rates of ovulation during the early and mid-anoestrous season following single injections of $\mathrm{Gn}-\mathrm{RH}$, and Crighton, Foster, Haresign, Haynes \& Lamming (1973) reported that 8/10 ewes ovulated after a single injection of 150 or $300 \mu \mathrm{g} \mathrm{Gn}-\mathrm{RH}$ in mid-anoestrus. These results may be due to the difference in treatment compared with the present study. One control ewe ovulated during late anoestrus (see Walton, Cunningham, Temple \& Bowman, 1974). Another ewe, infused with Gn-RH, apparently ovulated spontaneously, since the progesterone concentration was elevated for a period equal to the normal luteal phase and LH was elevated before infusion. The small number of large follicles found at endoscopy after a 1-day treatment and during early and late anoestrus was to be expected since the majority of mature follicles would have ovulated. The large follicles seen after a 3-day treatment period had probably grown as a result of gonadotrophin released during the 2nd and 3rd day infusions. Follicular growth as a result of Gn-RH treatment was not associated with increases in the secretion of oestrogen in either the breeding or anoestrous seasons.

Although endoscopy revealed that $10 / 11$ ewes had ovulated during the breeding season as a result of Gn-RH infusion, there was no evidence that the CL were functional (Lamond, Gaddy \& Kennedy, 1972). The transient release of progesterone which occurred during each Gn-RH infusion has previously been described by Baird \& Collett (1973) during infusion of a large dose of LH or HCG to a ewe with an auto-transplanted ovary containing a CL. According to Bedford, Harrison \& Heap (1972), there is an increased metabolic clearance rate for progesterone in the anoestrus of lactation, when compared with the breeding season. If the metabolic clearance rate is also high during seasonal anoestrus, then the concentrations of progesterone in the present study may not indicate rates of production.

All the animals which ovulated after Gn-RH infusion in the anoestrous season had lower progesterone concentrations than those found in a normal cycle and, in $11 / 15$, progesterone concentration was elevated for only a short time, suggesting a lack of normal luteal function, as has been described by Haresign, Haynes \& Lamming (1973) following single injections of Gn-RH.

The results of this study indicate the need for further investigation, both histological and biochemical, into the nature of the CL induced as a result of administration of $\mathrm{Gn}-\mathrm{RH}$ and into factors influencing $\mathrm{CL}$ maintenance.

This study was supported by the Libyan Government. We are grateful to the Wellcome Trust for a fellowship to K. B. and to the Libyan Government for a scholarship to A. M. S. We thank Dr L. E. Reichert and the NIH for generous gifts of protein hormones; Dr B. V. Caldwell, New Haven, Connecticut, and Dr C. R. N. Hopkinson, Frauenklinik, Marburg, Germany, for antisera; Dr A. L. Walpole and Dr H. Gregory of I.C.I., Alderley Park, Macclesfield, Cheshire, for a gift of synthetic Gn-RH, I.C.I. 82-286; and Miss H. Sillence for technical assistance.

\section{References}

Arimura, A., Debeluuk, L. \& Schally, A.V. (1972) Stimulation of FSH release in vivo by prolonged infusion of synthetic LH-RH. Endocrinology 91, 529-532.

Baird, D.T. \& Colletr, R.A. (1973) Progesterone secretion by the sheep corpus luteum after repeated infusions of luteinizing hormone and human chorionic gonadotrophin. J. Endocr. 57, 299-305.

Bedford, C.A., Harrison, F.A. \& Heap, R.B. (1972) The metabolic clearance rate and production rate of progesterone and the conversion of progesterone to 20a-hydroxypregn-4-en-3-one in the sheep. $J$. Endocr. 55, 105-118.

Chakraborty, P.K. \& Reeves, J.J. (1973) Pituitary responsiveness to infusion with LH-RH/FSH-RH. J. Anim. Sci. 37, 304, Abstr.

Cole, H.H. \& Mrller, R.F. (1935) Changes in the reproductive organs of the ewe with some data bearing on their control. Am. J. Anat. 57, 39-97.

Crighton, D.B., Foster, J.P., Haresign, W., Haynes, N.B. \& LAMming, G.E. (1973) The effects of a synthetic preparation of gonadotrophin releasing 
factor on pituitary and ovarian function in anoestrous ewes. J. Physiol., Lond. 231, 98P-99P.

Cumming, I.A., Buckmaster, J.M., Cerini, J.C., Cerini, M.E., Chamley, W.A., Findlay, J.K. \& GodING, J.R. (1972) Effect of progesterone on the release of luteinizing hormone induced by a synthetic gonadotrophin-releasing factor in the ewe. Neuroendocrinology 10, 338-348.

Debeluuk, L., Arimura, A. \& Schally, A.V. (1973) Stimulation of release of FSH and $\mathrm{LH}$ by infusion of LH-RH and some of its analogues. Neuroendocrinology 11, 130-136.

Domanski, E. \& Kochman, K. (1968) Induction of ovulation in sheep by intra-adenohypophysial infusion of hypothalamic extracts. $J$. Endocr. 42, 383-389.

Foster, J.P., Holland, D.T., Jeffcoate, S.L. \& Crighton, D.B. (1974) Simultaneous determination by radioimmunoassay of luteinizing hormone and luteinizing hormone releasing hormone at different stages of the oestrous cycle in the sheep. $J$. Endocr. 61, Ixii.

Goding, J.R., CatT, K.J., Brown, J.M., Kaltenbach, C.C., Cumming, I.A. \& Mole, B.J. (1969) Radioimmunoassay for ovine luteinizing hormone. Secretion of luteinizing hormone during estrus and following estrogen administration in the sheep. Endocrinology 85, 133-142.

HAMMOND, J., JR (1944) On the breeding season in the sheep. J. agric. Sci., Camb. 34, 97-105.

Haresign, W., Haynes, N.B. \& Lamming, G.E. (1973) The effects of synthetic gonadotrophin-releasing factor on ovarian function in anoestrous ewes. J. Reprod. Fert. 35, 600-601.

Hotchkiss, J., Atkinson, L.E. \& Knobil, E. (1971) Time course of serum estrogen and luteinizing hormone ( $\mathrm{LH}$ ) concentrations during the menstrual cycle of the Rhesus monkey. Endocrinology 89, 177-183.

Jonas, H.A., Salamonsen, L.S., Burger, H.G., Chamley, W.A., Cumming, I.A., Findlay, J.K. \& GoDING, J.R. (1973) Release of FSH after administration of gonadotrophin-releasing hormone or estradiol to the anestrous ewe. Endocrinology 92, 862-865.

Kaltenbach, C.C., DunN, T.G., Kiser, T.E., Corah, L.R., AKbar, A.M. \& Niswender, G.D. (1974) Release of FSH and LH in beef heifers by synthetic gonadotrophin releasing hormone. J. Anim. Sci. 38, $357-362$.

LAMOND, D.R., GADDY, R.G. \& KENNEDY, S.W. (1972) Infiuence of season and nutrition on luteal plasma progesterone in Rambouillet ewes. J. Anim. Sci. 34, 626-629.

Matsuo, H., Arimura, A., NaIr, R.M.G. \& Schally, A.V. (1971) Synthesis of the porcine LH and FSHreleasing hormone by the solid-phase method. Biochem. biophys. Res. Commun. 45, 822-827.

NetT, T.M., Akbar, A.M. \& NISWENDER, G.D. (1974) Serum levels of luteinizing hormone and gonadotrophin-releasing hormone in cycling, castrated and anestrous ewes. Endocrinology 94, 713-718.

Nillius, S.J. \& Wide, L. (1972) Variation in LH and FSH response to LH-releasing hormone during the 12 menstrual cycle. J. Obstet. Gynaec. Br. Commonw. 79, 865-873.

Niswender, G.D., Reichert, L.E., JR, Midgley, A.R., JR \& Nalbandov, A.V. (1969) Radioimmunoassay for bovine and ovine luteinizing hormone. Endocrinology 84, 1166-1175.

PANT, H.C. \& WARD, W.R. (1973) Effect of progesterone on the pituitary responsiveness to luteinizing hormone releasing hormone (LH-RH) in intact anoestrous ewes. J. Physiol., Lond. 232, 45P$47 \mathrm{P}$.

RADFORD, H.M., Wheatley, I.S. \& Wallace, A.L.C. (1969) The effects of oestradiol benzoate and progesterone on secretion of luteinizing hormone in the ovariectomized ewe. J. Endocr. 44, 135-136.

Reeves, J.J., Arimura, A. \& Schally, A.V. (1970) Studies on dose response relationship of luteinizing hormone-releasing hormone (LH-RH) in sheep. J. Anim. Sci. 31, 933-936.

Reeves, J.J., Arimura, A. \& Schally, A.V. (1971) Changes in pituitary responsiveness to luteinizing hormone-releasing hormone (LH-RH) in anestrous ewes pre-treated with estradiol benzoate. Biol. Reprod. 4, 88-92.

ReeVes, J.J., Arimura, A., Schally, A.V., Kragt, C.L., BECK, T.W. \& CASEY, J.M. (1972) Effects of synthetic luteinizing hormone-releasing hormone/follicle stimulating hormone-releasing hormone (LH-RH) FSH-RH) on serum LH, serum FSH and ovulation in anestrous ewes. J. Anim. Sci. 35, 84-89.

Reeves, J.J., Tarnavsky, G.K. \& Chakraborty, P.K. (1974) Serum LH in ewes treated with synthetic luteinizing hormone-releasing hormone/follicle stimulating hormone-releasing hormone (LH-RH) FSH-RH) at three periods of anestrus. J. Anim. Sci. 38, 369-373.

RIPPEL, R.H., MOYer, R.H., Johnson, E.S. \& MAUER, R.E. (1974) Response of the ewe to synthetic gonadotropin releasing hormone. J. Anim. Sci. 38, 605 $-612$.

RoBINSON, T.J. (1950) The control of fertility in sheep. I. Hormonal therapy in the induction of pregnancy in the anoestrous ewe. J. agric. Sci., Camb. 40, 275-307.

Roche, J.F., Foster, D.L., KarsCh, F.J., CoOK, B. \& DzIUK, P.J. (1970) Levels of luteinizing hormone in sera and pituitaries of ewes during the estrous cycle and anestrus. Endocrinology 86, 568-572.

RODBARD, D. (1971) Statistical aspects of radioimmunoassays. In Principles of Competitive ProteinBinding Assays, pp. 204-259. Eds W. D. Odell \& W. H. Daughaday. Lipincott, Philadelphia.

SCaramuzzi, R.J., Caldwell, B.V. \& Moor, R.M. (1970) Radioimmunoassay of $\mathrm{LH}$ and estrogen during the estrous cycle of the ewe. Biol. Reprod. 3, 110-119.

Schally, A.V., Redding, T.W., Matsuo, H. \& ArimurA, A. (1972) Stimulation of FSH and LH release in vitro by natural and synthetic $\mathrm{LH}$ and FSH releasing hormone. Endocrinology 90, 15611568.

Smeaton, T.C. \& Robertson, H.A. (1971) Studies on the growth and atresia of Graafian follicles in the ovary of the sheep. J. Reprod. Fert. 25, 243-252. 
Symons, A.M., Cunningham, N.F. \& Saba, N. (1974) The gonadotrophic hormone response of anoestrous and cyclic ewes to synthetic luteinizing hormonereleasing hormone. J. Reprod. Fert. 39, 11- 21.
Walton, J.S., Cunningham, F.T., Temple, A. \& Bowman, J.C. (1974) Luteinizing hormone and progesterone in the plasma of anoestrous ewes. J. Endocr. 61, lxxxii.

Received 18 June 1975 